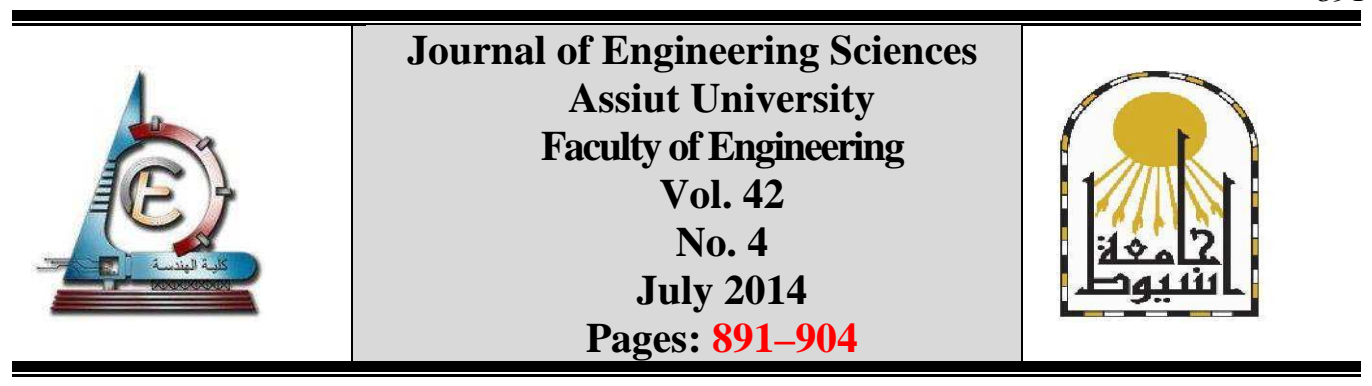

\title{
SIMULATION OF FLOW OVER WEIRS WITH BOTTOM PIPES (CASE STUDY: BAHR HASSAN WASEF WEIR)
}

\author{
Gamal Abozeid ${ }^{1}$, Ahmed M. El-Belasy ${ }^{2}$ and Salah M. Shehata ${ }^{3}$ \\ ${ }^{1}$ Professor in Civil Eng. Dept., Assiut Univ., Assiut, Egypt. \\ ${ }^{2}$ Associate Prof., Hydraulics Research Institute, National Water Research Center, Egypt. \\ ${ }^{3}$ Ministry of Water Resources and irrigation, Egypt.
}

Received 13 April 2014; accepted 11 May 2014

\begin{abstract}
The mathematical model is an idealization of a real system and it can be used to study the operation scenarios of an existing or a proposed system. The 1-D Sobek model is a mathematical model which is chosen to simulate the Fayoumi Standard weirs which have been modified by adding pipes to convey much water to downstream direction. Measurements of discharge with these structures are complicated due to existence of the pipes. Field measurements are carried out and simulated using mathematical model to investigate the effect of installing pipes on a clear over fall weir. Bahr Hassan Wasef is simulated with six cross-sections. A kilometer from the beginning of the channel including weir is represented. The used data of cross-sections altitudes, discharges, water levels upstream and downstream the weir, and the head over weir for Bahr Hassan Wasef were measured at the field by a Staff from Ministry of Water Resources and Irrigation in Al-Fayoum and Assiut Irrigation Directorates. The effect of downstream water depth is taken into consideration. The flow results of piped weir are compared with those of weir without pipes. It is found that there is a large difference between them. Equations and curves for computing the discharge of piped weirs are developed using multiple regression analysis on the bases of dimensional analysis. This research might help irrigation engineers to accurately estimate the discharge for such structures.
\end{abstract}

Keywords: Fayoumi Weirs, Simulation, Bottom Pipes, Free Discharge, Discharge Coefficient, 1- D Sobek.

\section{Introduction}

Developing new approaches for water management in Egypt where the high population growth coupled with shifts in the structure of the economy which are causing an increase in agricultural, municipal, industrial and tourism water demands from limited supplies is needed. Accurate delivery of the necessary amounts of water at the correct times can both conserve water and improve the quantity and quality of agricultural products [2 \& 7].

\footnotetext{
* Corresponding author.

Email address: salahshehata209@yahoo.com
} 
With the increase of cultivated area served by canals, water demands becoming higher. As a result, the capacity of the existing weirs built on those canals and the embankment of the canals themselves upstream of the weirs becoming insufficient to pass this increase of high water demands. So, the solution is to replace the old structures by new ones or to modify the existing ones [ $3 \& 6$ ]. The first solution is costly prohibitive while the second requires a modification of the hydraulics of the weirs. The modifications may be the widened or lowering weir crest or operating the existing pipes used at the bottom for emptying the canals to pass extra flow rates to downstream.

Wolters et al. [15] made serious attempts to distinguish between flow over the weir and the flow through the pipes. They suggested rating curves for studied weirs. Abdel halim et al.[1] introduced an equation for computing the discharge of weirs with orifices, but their equation is the dimensions of the used model. Combined flow over sharp-edged and below a gate with different shapes is simulated by Negm et al. [13]. General dimensionless relationships for predicting the discharge of the combined flow through these structures are introduced. Ministry of irrigation represented in Directorate of Water Distribution in Assiut Governorate [9 \& 10] estimated the values of discharge passing through weir with or without pipes by using own rating curves calculated from actual measurements in the field.

It is noticed that no general equations are found for estimating the discharge of the piped weirs, especially the contracted ones with bottom pipes. The main purpose of this research is to determine a general relationship for estimating the discharge of piped weirs.

\section{Theoretical approaches}

Two dependent variables are adequate to represent a one-dimensional flow. These equations are called Saint Venant equations [14]. They are derived on the bases of continuity equation and momentum one [6]. The used basic equations and the assumed hypothesis of the 1- D flow module are given here as follows:

1 - Continuity equation is given in the form;

$$
\frac{\partial A_{t}}{\partial t}+\frac{\partial Q}{\partial x}=0
$$

2- Momentum equation is given as;

$$
\frac{\partial Q}{\partial t}+\frac{\partial}{\partial x}\left(\alpha_{B} \frac{Q^{2}}{A_{f}}\right)+g A_{f} \frac{\partial h}{\partial x}+\frac{g Q|Q|}{C^{2} R A_{f}}=0
$$

in which:

$\mathrm{A}_{\mathrm{f}} \quad=$ conveying cross-section $\left[\mathrm{m}^{2}\right]$

$\mathrm{A}_{\mathrm{t}}=$ total cross-section area $\left[\mathrm{m}^{2}\right]$

$\mathrm{C}=$ Chézy coefficient $\left[\mathrm{m}^{1 / 2} / \mathrm{s}\right]$

$\mathrm{g}=$ acceleration due to gravity $\left[\mathrm{m} / \mathrm{s}^{2}\right]$

$\mathrm{h}=$ water level relative to the reference level [m]

$\mathrm{Q}=$ total discharge $\left[\mathrm{m}^{3} / \mathrm{s}\right]$

$\mathrm{R}=$ hydraulic radius (approximately equals to water depth [m]

$\mathrm{t}=$ time $[\mathrm{s}]$

$\mathrm{W}_{\mathrm{f}}=$ width of conveying cross-section at water surface [m] 
$\mathrm{x} \quad=$ distance along the channel $[\mathrm{m}]$

$\alpha_{\mathrm{B}}=$ Boussinesq coefficient (Eq. (3)) [-]

The Boussinesq coefficient is a correction factor in the convective acceleration term Eq. (2), to account for non-uniform velocity distribution in the cross-section. It is computed as follows [5][14]:

$$
\alpha_{\mathrm{B}}=\frac{\sum_{\mathrm{i}=1}^{\mathrm{n}} \mathrm{C}_{\mathrm{i}}{ }^{2} \mathrm{R}_{\mathrm{i}} \mathrm{A}_{\mathrm{fi}}}{\mathrm{C}^{2} \mathrm{R}_{\mathrm{f}}} \quad \text { and } \quad C^{2} R=\left[\frac{\sum_{i=1}^{n} C_{i} A_{f i} \sqrt{R_{i}}}{A_{f}}\right]^{2}
$$

where: $\mathrm{i}=$ index indicating type of sub-section in conveying cross-section $(\mathrm{i} \leq 3)$

The last expression in Eq. (3), computing a representative $\mathrm{C}^{2} \mathrm{R}$, is also used in the bedfriction term in Eq. (2). Chézy coefficient $\mathrm{C}$ in this model computed as a function of Manning's roughness coefficient $\mathrm{n}_{\mathrm{m}}$ :

$$
C=\frac{R^{\frac{1}{6}}}{n_{m}}
$$

For the canal model, the Manning type roughness coefficient may provide a good representation of the hydraulic roughness for a wide range of discharges [6]. Flow over a rectangular weir with lateral contractions and a non- submerged hydraulic jump can be described by [1]:

$$
Q_{\text {actw }}=\frac{2}{3} C_{d w}(b-0.1 n H) \sqrt{2 g} H^{1.5} \text { (Contracted-weir) }
$$

or

$$
Q_{a c t w}=C_{1} H^{1.5}
$$

In which $\mathrm{Q}_{\mathrm{actw}}$ is the actual discharge passes over the weir, $\mathrm{C}_{\mathrm{dw}}$ is the weir coefficient of discharge, $b$ is the width of the weir crest, $n$ is the number of end contractions, $g$ is the gravitational acceleration, and $\mathrm{H}$ is the water head over the weir. Also, Flow through the pipe is governed by the following equation for the orifice discharge [1]:

$$
Q_{\text {actp }}=\left(\frac{\pi}{4} D^{2}\right) C_{d p} \sqrt{2 g H_{P}}
$$

or

$$
Q_{\text {actp }}=\mathrm{C}_{2} \mathrm{H}_{p}^{0.5}
$$

In which $Q_{a c t p}$ is the actual discharge through the pipe, $\mathrm{C}_{\mathrm{dp}}$ is the pipe coefficient of discharge, $g$ is gravitational acceleration, and $\mathrm{H}_{\mathrm{p}}$ is the difference of head of water acting on the pipe, see Fig. (1). 


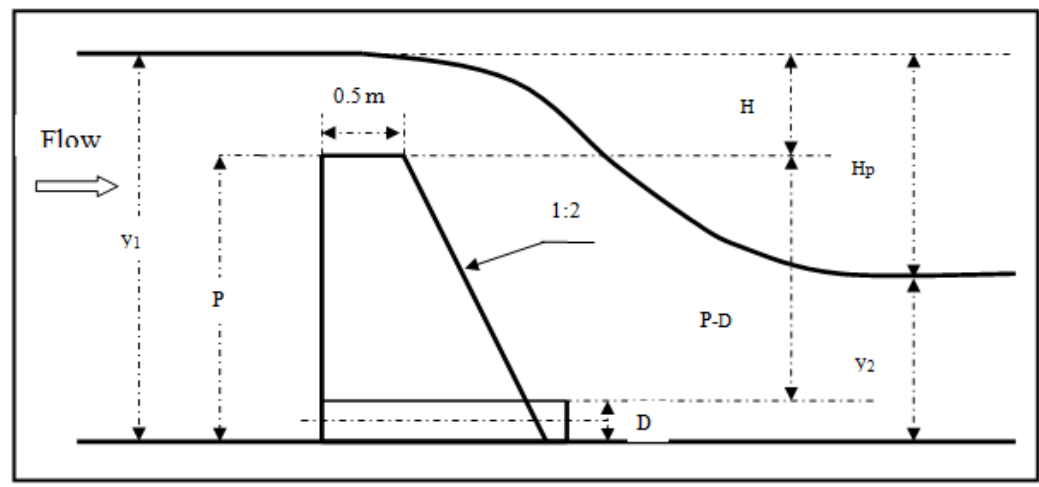

Fig. 1. Definition sketch of a piped weir.

Thus, any relationship controls the flow passing over combined structure (Qact) consisted of weir and pipe must use these equations to illustrate the interaction that may be happened. From Eq. ${ }^{\mathrm{s}}$ ( $5 \mathrm{~b} \& 6 \mathrm{~b}$ ), the following equation for estimating the discharge of piped weirs is given as:

$$
Q=C_{1} H^{1.5}+C_{2} H_{p}^{0.5}
$$

The values of $C_{1}$ and $C_{2}$ may be experimentally or mathematically estimated. In this research, the values of these parameters are mathematically estimated using 1-D SOBEK model.

\section{Bahr Hassan Wasef Weir (case study)}

\subsection{Model area}

Baher Hassan Wassef is a canal of $13.8 \mathrm{~km}$ long and is located in AL Fayoum governorate. The designed bed width of the canal is $16.0 \mathrm{~m}$ with a bed and water surface slope of $10 \mathrm{~cm} / \mathrm{km}$. The canal bed level is $21.50 \mathrm{~m}$ at its start. As there is a $0.40 \mathrm{~m}$ drop in the longitudinal section at $0.9 \mathrm{~km}$, its bed level is $19.70 \mathrm{~m}$ at its end. AL Fayoum type weir was constructed downstream the barrage at a distance of $0.90 \mathrm{~km}$ to measure the discharge passing through the canal. Weir crest level is $24.48 \mathrm{~m}$ with designed maximum upstream water level of $25.8 \mathrm{~m}$ and downstream one of $24.50 \mathrm{~m}$. Weir dimensions and levels are shown below [6, $11 \& 12]$.

\subsection{Model components}

Most of model components, limits of data introduced in the 1- D SOBEK model and the geometry of Hassan Wasef weir are summarized as shown in Table (1).

The distance between the grid points in each reach, in the distance represented the weir and the pipe system is taken as $1.0 \mathrm{~m}$, while it is taken as $100 \mathrm{~m}$ for Hasan Wasef model. For model calculations, time step are taking one hour. Total time for stimulation is taken 24 hours. Grid points are defined to represent the spatial numerical grid on which the partial differential equations are solved. Chosen of spatial steps provide a good balance between numerical accuracy (high accuracy for considered scales) and computational effort (computational time and amount of output data to be processed) [4, $5 \& 6]$. The working discharge of Hassan Wasef weir is taken as upstream boundary condition, while 
the downstream water levels which represents the state of pipe submergence are taken as downstream boundary conditions.

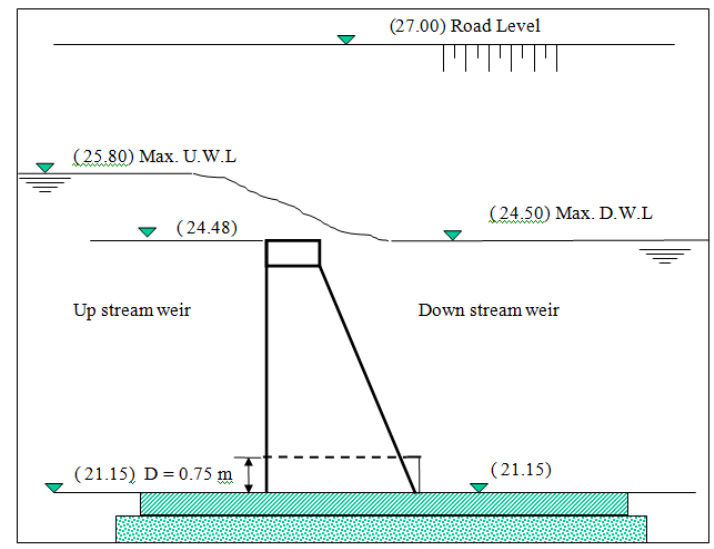

Fig. 2. Dimensions of Bahr Hassan Wasef weir.

Table 1.

Dimensions of the Bahr Hassan Wasef modeled structures.

\begin{tabular}{|c|c|c|c|c|c|c|c|c|}
\hline Model. & $\begin{array}{c}\text { Bed } \\
\text { Level }\end{array}$ & $\begin{array}{c}\text { Up } \\
\text { stream } \\
\text { W.L }\end{array}$ & $\begin{array}{c}\text { Down } \\
\text { stream } \\
\text { W.L }\end{array}$ & $\mathrm{D}(\mathrm{m})$ & $\mathrm{P}(\mathrm{m})$ & $\mathrm{b}(\mathrm{m})$ & $\mathrm{H}(\mathrm{m})$ & $\mathrm{H}_{\mathrm{p}}(\mathrm{m})$ \\
\hline $\begin{array}{c}\text { One pipe } \\
\text { only }\end{array}$ & 21.15 & $\begin{array}{c}22.5 \text { to } \\
25.8\end{array}$ & $\begin{array}{c}22.5 \text { to } \\
24.5\end{array}$ & 0.75 & - & - & - & 0 to 3.3 \\
\hline $\begin{array}{c}\text { Two pipes } \\
\text { only }\end{array}$ & 21.15 & $\begin{array}{c}22.5 \text { to } \\
25.8\end{array}$ & $\begin{array}{c}22.5 \text { to } \\
24.5\end{array}$ & 0.75 & - & - & - & 0 to 3.3 \\
\hline $\begin{array}{c}\text { Weir } \\
\text { without } \\
\text { pipes }\end{array}$ & 21.15 & $\begin{array}{c}22.5 \text { to } \\
25.8\end{array}$ & $\begin{array}{c}22.5 \text { to } \\
24.5\end{array}$ & - & 3.33 & 15 & $\begin{array}{c}0 \text { to } \\
1.3\end{array}$ & 0 to 3.3 \\
\hline $\begin{array}{c}\text { One piped } \\
\text { weir }\end{array}$ & 21.15 & $\begin{array}{c}22.5 \text { to } \\
25.8\end{array}$ & $\begin{array}{c}22.5 \text { to } \\
24.5\end{array}$ & $\begin{array}{c}1 \times 0.7 \\
5\end{array}$ & 3.33 & 15 & $\begin{array}{c}0 \text { to } \\
1.3\end{array}$ & 0 to 3.3 \\
\hline $\begin{array}{c}\text { Two piped } \\
\text { weir }\end{array}$ & 21.15 & $\begin{array}{c}22.5 \\
\text { to } 25.8\end{array}$ & 22.5 to 24.5 & $\begin{array}{c}2 \times 0.7 \\
5\end{array}$ & 3.33 & 15 & $\begin{array}{c}0 \text { to } \\
1.3\end{array}$ & 0 to 3.3 \\
\hline
\end{tabular}

\subsection{Model simulation and calibration}

The constructed mathematical model has been calibrated using the measured data and obtained information. The model was calibrated based on assuming roughness values and using the trial and error technique until the output of the model matched the measured field data of the water levels and discharges. The average roughness value is computed and taken 0.0276 for channel. The recent measured cross sections obtained in year 2013 by Irrigation General Directorate of West Al Fayuom Staff [11\&12] for Bahr Hassan Wasef. Also head over the weir, water level downstream of the weir, and discharges through weir without pipe, one piped weir, and two piped weir were measured two times for the three cases and are listed in Table (2). These data enabled a better calibration of the investigated weir. 
Table 2.

The measured data which are used for calibrating the model

\begin{tabular}{|c|c|c|c|c|c|c|}
\hline Weir Case & $\begin{array}{c}\text { Water level } \\
\text { At HWBR } \\
(\mathrm{m})\end{array}$ & $\begin{array}{c}\text { Water level } \\
\text { US Weir } \\
(\mathrm{m})\end{array}$ & $\begin{array}{c}\text { Water } \\
\text { level DS } \\
\text { Weir } \\
(\mathrm{m})\end{array}$ & $\begin{array}{c}\text { Water } \\
\text { Head over } \\
\text { Weir } \\
\mathrm{H}(\mathrm{m})\end{array}$ & $\begin{array}{c}\text { Discharge } \\
\mathrm{Q}\left(\mathrm{m}^{3} / \mathrm{s}\right)\end{array}$ & Date \\
\hline $\begin{array}{c}\text { Weir without } \\
\text { pipe }\end{array}$ & 25.59 & 25.54 & 24.19 & 1.06 & 33.45 & $1 / 1 / 2013$ \\
\cline { 2 - 7 } & 25.80 & 25.74 & 24.50 & 1.26 & 43.30 & $19 / 8 / 2013$ \\
\hline $\begin{array}{c}\text { One piped } \\
\text { weir }\end{array}$ & 25.55 & 25.51 & 24.19 & 1.03 & 33.45 & $2 / 1 / 2013$ \\
\cline { 2 - 7 } & 25.80 & 25.74 & 24.5 & 1.26 & 45.20 & $20 / 8 / 2013$ \\
\hline $\begin{array}{c}\text { Two piped } \\
\text { weir }\end{array}$ & 25.52 & 25.47 & 24.22 & 0.99 & 33.45 & $3 / 1 / 2013$ \\
\cline { 2 - 7 } & 25.80 & 25.74 & 24.50 & 1.26 & 46.70 & $21 / 8 / 2013$ \\
\hline
\end{tabular}

Manning roughness values obtained during the calibration were used in SOBEK model. The results of calibrations are plotted and shown in Fig. (3).

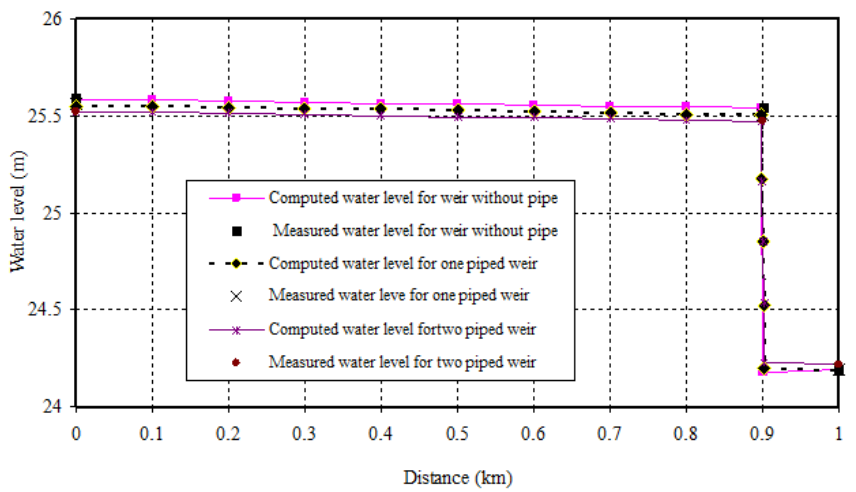

Fig. 3. Results of calibration process for weir without pipes, one pipe, and two piped weir at $\mathrm{Q}=33.45 \mathrm{~m}^{3} / \mathrm{s}$ (Bahr Hassan Wasef).

\subsection{Model verification and validation}

Verification of Bahr Hassan Wasef model is carried out based on real measurements. These measurements are shown in Table (3). A comparison of measured water levels and computed values are shown in Fig. (4).

\section{Results and discussions}

The discharges and water levels were measured during closing the pipes and after opening them. The measurements were used as input data to SOBEK model. The model was then run and the discharge was predicted for every simulated case. Based on the model results, formulas are established. These formulas are validated against field measurements and compared with previous studies.

\subsection{Weirs without Pipes}

Shown in Fig. (5) are the results of Sobek model; the discharge Q against head H. The curve can be represented by the following form:

$$
Q_{w}=30.69 H^{1.5}, 0.0 \mathrm{~m}<\mathrm{H}<1.3 \mathrm{~m}\left(\mathrm{R}^{2}=1.0\right)
$$

Comparing Eq. $(5-a)$ to Eq. (8), the value of $\mathrm{C}_{\mathrm{dw}}$ may equal to 0.69 
JES, Assiut University, Faculty of Engineering, Vol. 42, No. 4, July 2014, pp. 891-904

\section{Table 3.}

The measured data which are used for the verification of the model

\begin{tabular}{|c|c|c|c|c|c|c|}
\hline Weir Case & $\begin{array}{c}\text { Water } \\
\text { level } \\
\text { At } \\
\text { HWBR } \\
\text { (m) }\end{array}$ & $\begin{array}{l}\text { Water level } \\
\text { US Weir } \\
\text { (m) }\end{array}$ & $\begin{array}{l}\text { Water level } \\
\text { DS Weir } \\
\text { (m) }\end{array}$ & $\begin{array}{c}\text { Water Head } \\
\text { over Weir } \\
\text { H (m) }\end{array}$ & $\begin{array}{c}\text { Discharge } \\
\mathrm{Q}\left(\mathrm{m}^{3} / \mathrm{s}\right)\end{array}$ & Date \\
\hline \multirow{5}{*}{$\begin{array}{c}\text { Weir } \\
\text { without pipe }\end{array}$} & 24.90 & 24.89 & 23.80 & 0.41 & 7.913 & $20 / 1 / 2013$ \\
\hline & 25.13 & 25.12 & 24.0 & 0.64 & 15.632 & $26 / 1 / 2013$ \\
\hline & 25.28 & 25.25 & 24.12 & 0.77 & 20.833 & $30 / 1 / 2013$ \\
\hline & 25.50 & 25.46 & 24.17 & 0.98 & 29.606 & $26 / 4 / 2013$ \\
\hline & 25.73 & 25.66 & 24.25 & 1.18 & 39.296 & $10 / 7 / 2013$ \\
\hline \multirow{5}{*}{$\begin{array}{l}\text { One piped } \\
\text { weir }\end{array}$} & 24.85 & 24.83 & 23.8 & 0.35 & 7.913 & $20 / 1 / 2013$ \\
\hline & 25.10 & 25.08 & 24.10 & 0.6 & 15.632 & $26 / 1 / 2013$ \\
\hline & 25.25 & 25.22 & 24.15 & 0.74 & 20.833 & $30 / 1 / 2013$ \\
\hline & 25.46 & 25.42 & 24.19 & 0.94 & 29.606 & $26 / 4 / 2013$ \\
\hline & 25.68 & 25.63 & 24.25 & 1.15 & 39.296 & $10 / 7 / 2013$ \\
\hline \multirow{5}{*}{$\begin{array}{l}\text { Two piped } \\
\text { weir }\end{array}$} & 24.8 & 24.79 & 23.85 & 0.31 & 7.913 & $20 / 1 / 2013$ \\
\hline & 25.07 & 25.04 & 24.10 & 0.56 & 15.632 & $26 / 1 / 2013$ \\
\hline & 25.21 & 25.18 & 24.15 & 0.70 & 20.833 & $30 / 1 / 2013$ \\
\hline & 25.43 & 25.39 & 24.20 & 0.91 & 29.606 & $26 / 4 / 2013$ \\
\hline & 25.65 & 25.60 & 24.27 & 1.12 & 39.296 & $10 / 7 / 2013$ \\
\hline
\end{tabular}

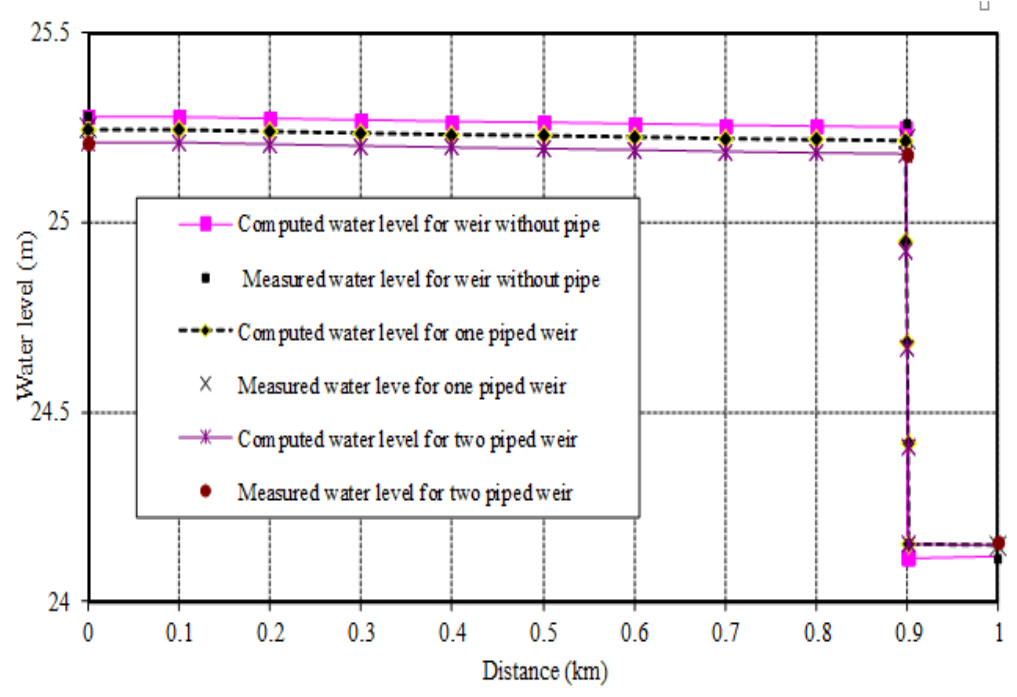

Fig. 4. Results of verification process for weir without pipes, one pipe, and two piped weir at $\mathrm{Q}=20.83 \mathrm{~m}^{3} / \mathrm{s}$ (Bahr Hassan Wasef). 


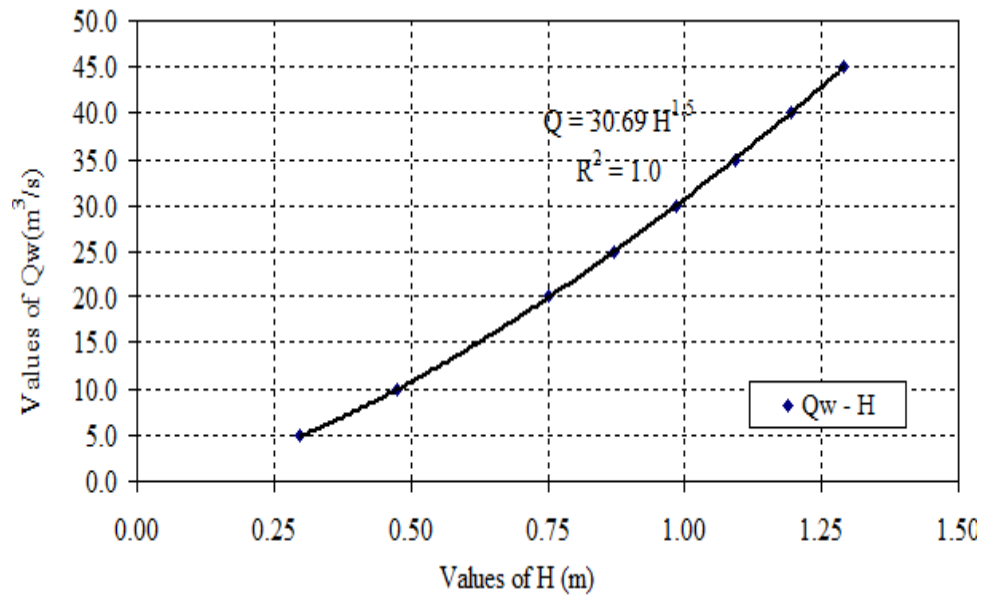

Fig. 5. Predicted discharge, $Q_{w}$ versus head, $H$ over Hassan Wasf weir without pipe.

\subsection{Weir with one or two bottom pipes}

Shown in Fig. (6) are the plots of Sobek model results of discharge $\mathrm{Q}_{\mathrm{p}}$, against head $\mathrm{H}_{\mathrm{p}}$ for one and two pipes. It can be seen that; for one pipe, the data are simulated by a curve. This curve has the following form;

$$
Q_{p}=1.46 H_{p}^{0.5}, 0.0 \mathrm{~m}<\mathrm{H}_{\mathrm{p}}<3.3 \mathrm{~m}\left(\mathrm{R}^{2}=1.0\right)
$$

From the degining Eq. ( 6 - a) and Eq. (9), the value of $C_{d p}$ for one pipe only may equal to 0.74 .

Similarly, for weir provided with two pipes, the curve can be represented by;

$$
Q_{p}=2.75 H_{p}{ }^{0.5} 0 \mathrm{~m}<\mathrm{H}_{\mathrm{p}}<3.3 \mathrm{~m}\left(\mathrm{R}^{2}=1.0\right)
$$

Referring to Eq. (6 - a) with Eq. (10), the value of $\mathrm{C}_{\mathrm{dp}}$ for two pipes only may equal to 0.703 .

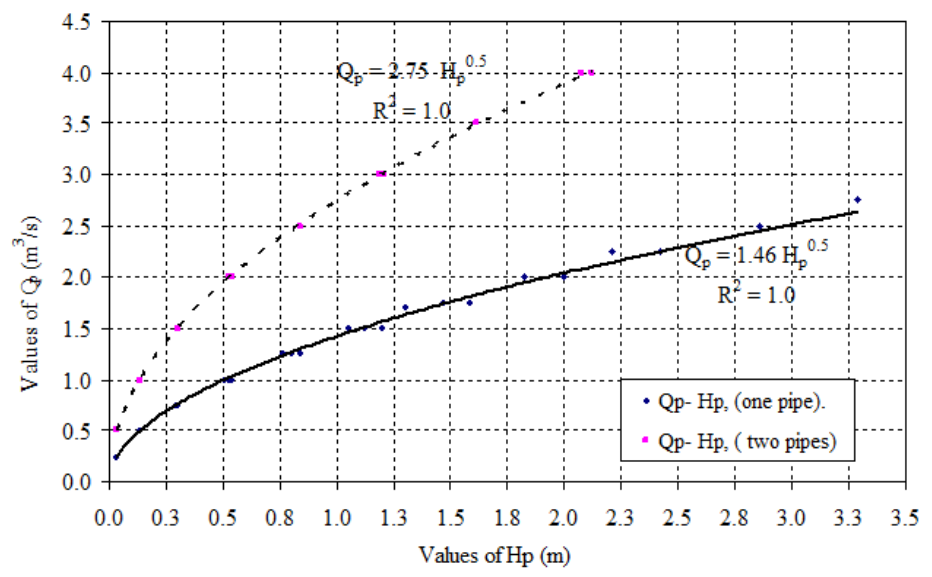

Fig. 6. Predicted discharge, $Q_{p}$ versus head, $H_{p}$ acting on the pipes $(m)$ 


\subsection{Discharge through piped weir}

The plots of Sobek model results of discharges over weir crest, $\mathrm{Q}_{\mathrm{W}}$ and that through one bottom pipe, $\mathrm{Q}_{\mathrm{P}}$ against the acting heads over weir crest, $\mathrm{H}$ and the acting head over pipe, $\mathrm{H}_{\mathrm{p}}$ for one piped weir are shown in Fig. (7). Actually, there are no meanings of the point of intersection of the two curves of $\mathrm{Q}_{\mathrm{w}}-\mathrm{H}_{\mathrm{w}}$ and $\mathrm{Q}_{\mathrm{p}}-\mathrm{H}_{\mathrm{p}}$, as they are plotted on two different scales. It can be observed that the data are represented by the following formula with $\mathrm{R}^{2}=1.00$;

$$
Q=1.37 H_{p}^{0.5}+30.69 H^{1.5}\left(\mathrm{R}^{2}=1.0\right)
$$

Referring to Eq. ( $5 \& 6$ ) with Eq. (11), the value of $\mathrm{C}_{\mathrm{dw}}=0.69$ and $\mathrm{Cd}_{\mathrm{p}}=0.7$ for one piped weirs

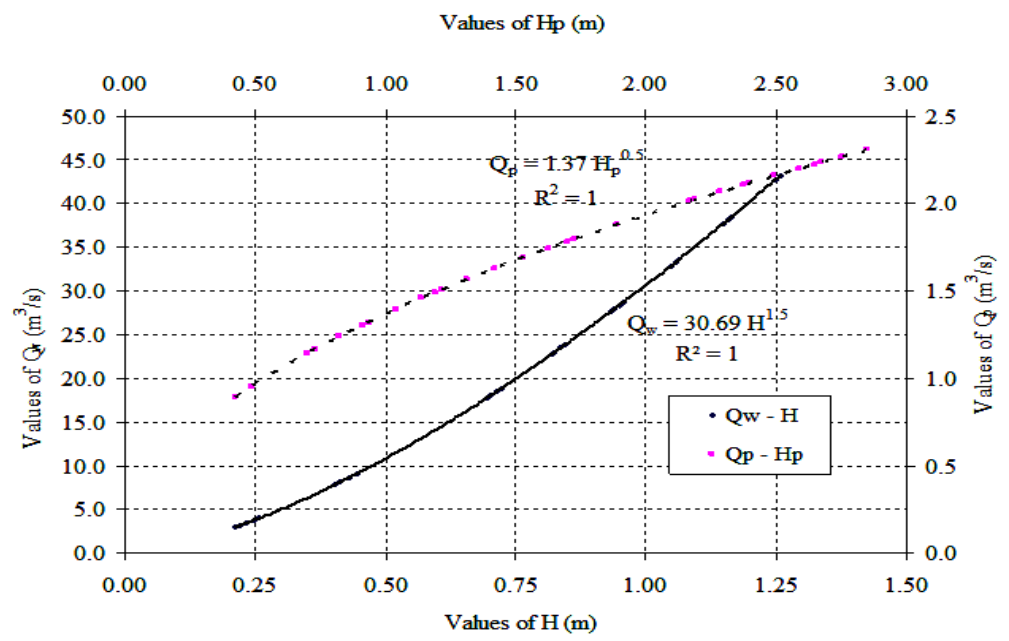

Fig. 7. Computed discharges $\mathrm{Q}_{w}$ and $\mathrm{Q}_{\mathrm{p}}$. versus $\mathrm{H}, \mathrm{H}_{\mathrm{p}}$ for Hassan Wasf weir with one bottom pipe.

Also, Sobek model results of discharges over weir crest, $\mathrm{Qw}$ and that through two bottom pipes, $\mathrm{Q}_{\mathrm{P}}$. against the acting heads over weir crest, $\mathrm{H}$ and the acting head over pipes, $H_{p}$ for two piped weir are shown in Fig. (8). As mentioned above, there are no meanings of the point of intersection of the two curves of $\mathrm{Q}_{w}-\mathrm{H}_{w}$ and $\mathrm{Q}_{\mathrm{p}}-\mathrm{H}_{\mathrm{p}}$, as they are plotted on two different scales. It can be observed that the data are represented by the following formula;

$$
Q=2.73 H_{p}^{0.5}+30.69 H^{1.5}\left(\mathrm{R}^{2}=1.0\right)
$$

Thus, for two piped weirs, the value of $\mathrm{C}_{\mathrm{dw}}=0.69$ and $\mathrm{Cd}_{\mathrm{p}}=0.7$. 
Values of $\mathrm{Hp}(\mathrm{m})$

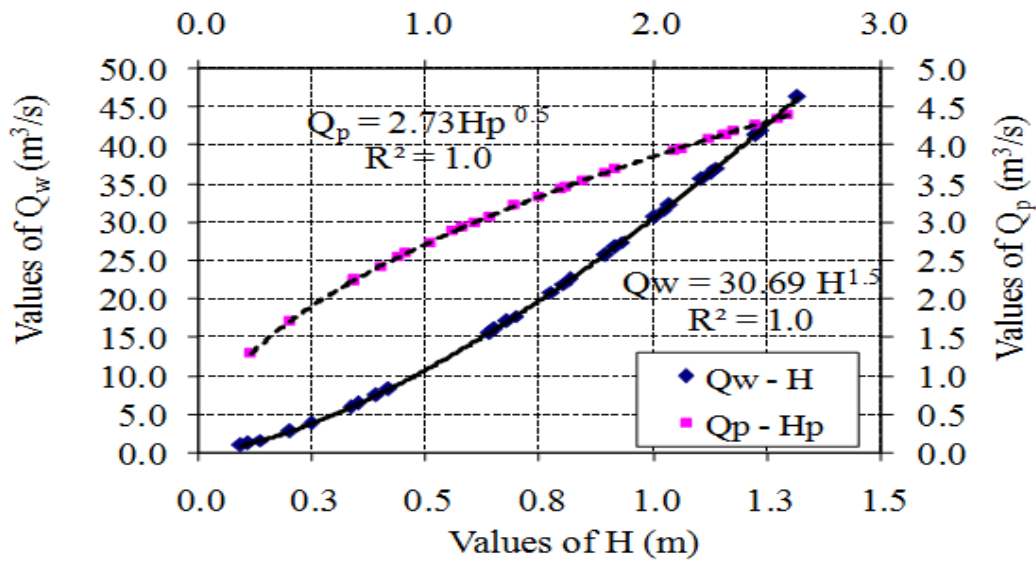

Fig. 8. Computed discharges $\mathrm{Q}_{w}$ and $\mathrm{Q}_{\mathrm{p}}$. versus $\mathrm{H}, \mathrm{H}_{\mathrm{p}}$ for Hassan Wasf weir with two bottom pipes.

\subsection{Rating curves}

Rating curves help engineers and user to get information easy and faster. Now, we are going to have a relationship between the rate of flow $(\mathrm{Q})$ and the head over the weir or that acting on the pipes. In previous studies [6][8][9][10], the relationship between the discharge in the channel with the head over the weir crest was represented only. They didn't take into consideration the effect of the head difference between upstream and downstream water level which affects the flow rate through pipes. To achieve better understanding, the data obtained from previous studies are shown in Figs. (9 -11) and Table (4). From Fig. (9), for $\mathrm{H}$ less than a unity (m), the given discharge from equations having head $(\mathrm{H})$ with power more than 1.5 is smaller than that given with power equals to 1.5. This may be due to that, in the previous studies, the discharges through pipes due to actually water head over the pipes were not taken into account. This concludes that there is much more amount of water passed through pipes and was not calculated in previous calculations. Figs. $(10 \& 11)$ show the plots of rating curves for the weir and pipes taking into consideration the acting head on the pipe and that on the weir crest individually, taking the interference effect in account.

Table 4.

Equations control relationship between $\mathrm{Q}$ and $\mathrm{H}$ for Hassan Wasef weir

\begin{tabular}{|c|c|c|c|c|c|c|c|c|}
\hline & \multicolumn{2}{|c|}{ MWRI [9] } & \multicolumn{2}{|c|}{ El-belasy [6] } & \multicolumn{2}{|c|}{$\begin{array}{c}\text { Practical Discharge } \\
\text { measurements [9] }\end{array}$} & \multicolumn{2}{|c|}{ The author } \\
\hline Weir case & Equation & $\mathrm{R}^{2}$ & Equation & $\mathrm{R}^{2}$ & Equation & $\mathrm{R}^{2}$ & Equation & $\mathrm{R}^{2}$ \\
\hline One pipe & - & - & - & - & - & - & $1.45 \mathrm{H}_{\mathrm{p}}^{0.5}$ & 1 \\
\hline Two pipes & - & - & - & - & - & - & $2.75 \mathrm{H}_{\mathrm{p}}^{0.5}$ & 1 \\
\hline $\begin{array}{c}\text { Weir } \\
\text { Without } \\
\text { Pipes }\end{array}$ & $31.18 \mathrm{H}^{1.9493}$ & - & - & - & $\begin{array}{c}32.84 \mathrm{H}^{1.5} \\
\text { Or } \\
32.348 \mathrm{H}^{1.8415} \\
\end{array}$ & & $30.69 \mathrm{H}^{1.5}$ & 1 \\
\hline $\begin{array}{l}\text { One piped } \\
\text { weir }\end{array}$ & - & - & $\begin{array}{c}32.1 \mathrm{H}^{1.5} \\
\text { or } \\
32.1 \mathrm{H}^{1.72}\end{array}$ & - & - & & $\begin{array}{c}30.69 \mathrm{H}^{1.5} \\
+ \\
1.37 \mathrm{H}_{\mathrm{p}}^{0.5}\end{array}$ & 1 \\
\hline $\begin{array}{l}\text { Two piped } \\
\text { weir }\end{array}$ & - & - & $\begin{array}{c}33.6 \mathrm{H}^{1.5} \\
\text { or } \\
34.2 \mathrm{H}^{1.63}\end{array}$ & - & - & & $\begin{array}{c}30.69 \mathrm{H}^{1.5} \\
+ \\
2.73 \mathrm{H}_{\mathrm{p}}^{0.5}\end{array}$ & 1 \\
\hline Remarks & \multicolumn{2}{|c|}{$\begin{array}{l}\text { No pipe is taken into } \\
\text { consideration }\end{array}$} & \multicolumn{2}{|c|}{$\begin{array}{l}\text { No downstream WL } \\
\text { is taken into } \\
\text { consideration }\end{array}$} & \multicolumn{2}{|c|}{$\begin{array}{l}\text { No pipe is taken into } \\
\text { consideration }\end{array}$} & \multicolumn{2}{|c|}{$\begin{array}{l}\text { downstream WL and } \\
\text { piped cases are taken } \\
\text { into consideration }\end{array}$} \\
\hline
\end{tabular}




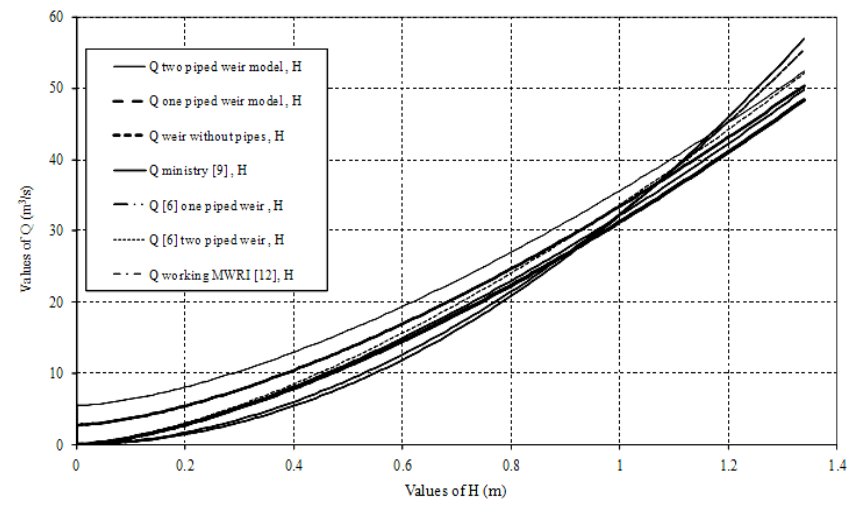

Fig. 9. Rating curve for Hassan Wasf piped weir.

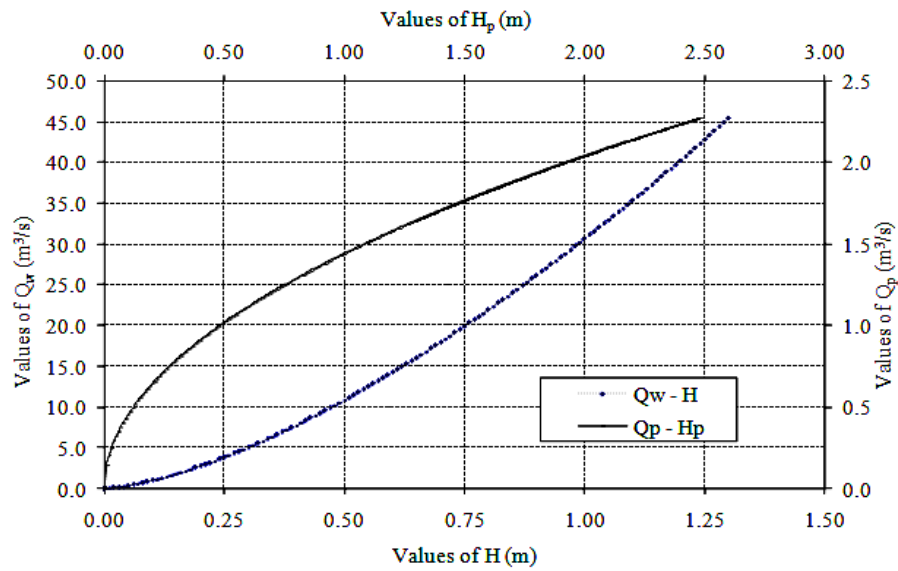

Fig. 10. Rating curve for Hassan Wasf weir with one pipe Eq. (11).

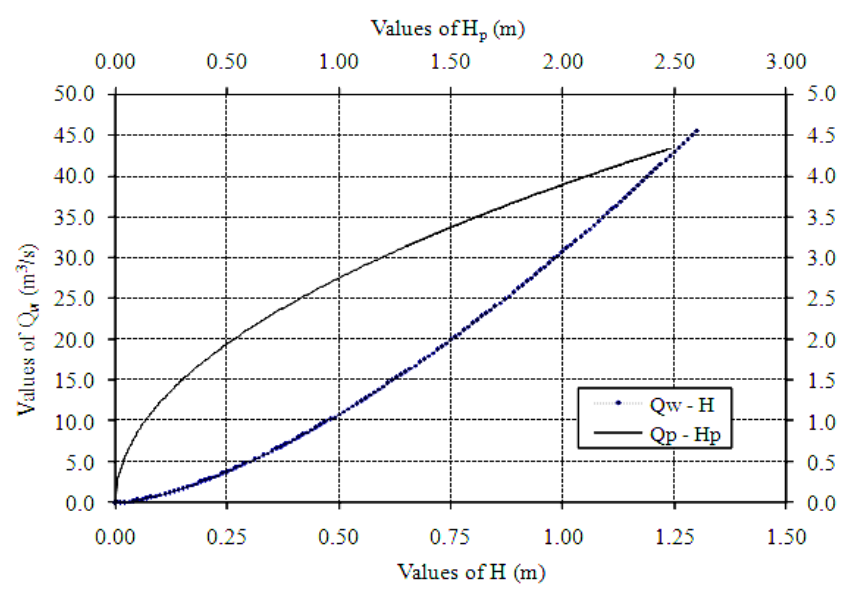

Fig. 11. Rating curve for Hassan Wasf weir with two pipes Eq. (12). 


\section{Conclusions}

The finding from this research may have practical applications, especially when operating the existing bottom pipes to increase the conveyance efficiency of the channel upstream the weirs and also to increase the discharge passing to downstream channel. The following main conclusions may be drawn:

1- The division of flow passing with combined structure (weir provided with bottom pipes) affected by the flow characteristics downstream, as the pipe discharge depends mainly on the difference between upstream water level and the downstream ones.

2- Operating the bottom pipes for passing flow with that passes over the weir crest improves the discharge coefficient of the weir and the pipe.

3- The downstream water depth affects the upstream water depth for weir with bottom pipes when the pipes become submerged.

4- 1-D SOBEK model is an efficient tool for predicting equations for computing the discharge through the combined device for the same conditions of derivation.

5- Using mathematical model in modelling flow over piped weir may help engineers for well design and prediction scenarios when working the pipes with the weirs.

6- It is recommended to develop rating curves for weirs with pipes for all Fayoumi standard piped weirs to contribute in controlling flow rate over those structures.

7- Equation and rating curves are awarded for estimating the flow rates of the combined structures of weirs and bottom pipes.

\section{REFERENCES}

[1] Abdel Halim, N. A., Sherif, M. M., and El-Zaher, A. S., "On the Fayoum Weirs with Orifices ", J. of Eng. and Applied Scie., Faculty of Eng., Cairo Univ., Egypt, Vol. 38, No. 5, pp. 893-904. 1991.

[2] Abouzeid, G., "Improvement of The Hydraulic Performance of Sharp-crested Side Weirs in Circular Channels", International Water Technology Conference, IWTC8 2004, Egypt. pp. 499-509, 2004.

[3] Abozeid, G., Mohamed, H. I., and Shehata, S. M., "Hydraulic of Clear Overfall Weirs with Bottom-Openings", JES, Assiut University, vol. 38, no. 1, pp 19-28, 2010.

[4] Ansar, M., "Discussion of Simultaneous Flow Over and Under a Gate" J. of Irrig.\& Drain. Eng., pp. 325-328, 2001.

[5] El-Belasy, A.M., Study of the discharge capacity of the Damietta Branch for high flows. HRI report No. 108/2004. 2004.

[6] El-Belasy, A.M., Developing formulae for combined weir and orifice (case study: ElFayoum weirs), Alexandria, Engineering Journal, Vol.52, pp. 763-768, 2013.

[7] Hassan I. Mohamed, Gamal Abozeid, and Salah M. Shehata, "Hydraulic of Clear and Submerged Overfall Weirs with Bottom Circular - Openings, J. of Faculty of Engineering, Ain Shams University, Vol. (1), pp 115-119, 2010.

[8] Mohamed, H. I., "Discharge Measurement in Trapezoidal Lined Canals Utilizing Horizontal and Vertical Transitions" Ninth International Water Technology Conference, IWTC9, Sharm El-Sheikh, Egypt, pp. 263-275, 2005.

[9] MWRI, Ministry of Water Recourses and Irrigation, General Directorate for water Distribution, Assiut, Egypt, "Calibration Tables of Irrigation Channels”, 1999-2013.

[10] MWRI, Ministry of Water Recourses and Irrigation, General Directorate for water Distribution, Assiut, Egypt, "Daily Table Reading Levels of Irrigation Channels", 19992013.

[11] MWRI, Ministry of Water Recourses and Irrigation, General Directorate of Irrigation for 
West Fayoum, Fayoum, Egypt, “Cross Sections of Hassan Wasef Weir”, 2013.

[12] MWRI, Ministry of Water Recourses and Irrigation, General Directorate of Irrigation for West Fayoum, Fayoum, Egypt, "Working Discharge Measurements of Hassan Wasef Weir", 2013.

[13] Negm, A. M., Al-Brahim, A. M., Alhamid, A. A.,"Combined-free Flow over Weirs and below Gates", J. of Hyd. Res., Vol. 40, No. 3, pp.359-365, 2002.

[14] WL| Delft Hydraulics, "SOBEK River/Estuary User Manual”, SOBEK Help Desk, 2005.

[15] Wolters, W., ghobrial, N. S. and Eisa, M.,"Calibration of weirs in The Fayoum, Egypt", Irrig. \& Drain. Syst., 1, pp. 173-185, 1987. 


\section{محاكاة السريان على الهدارات الحرة ذات المواسير السفلية (دراسة حالة هدار حسن واصف باقليم الفيوم)}

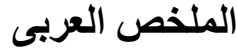

مع استخدام أجهزة الحاسبات الشخصية الحديثة أصبح استخدام النمـاذج الرياضية أكثر سـر عة وأقل تكلفة و

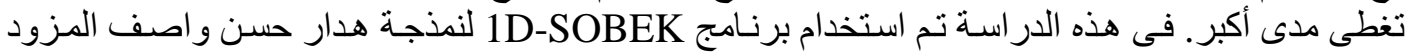

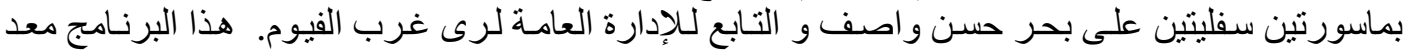

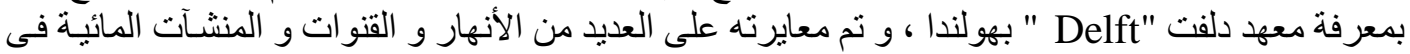

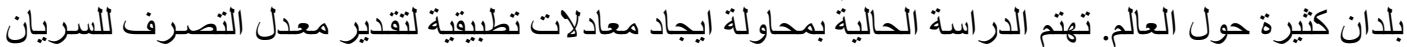

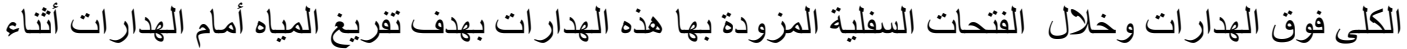

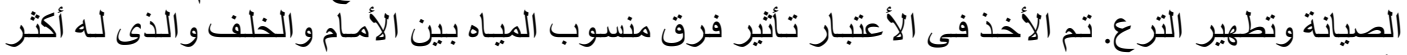
تأثير ا على السريان بالمو اسير

أجريت الدر اسة بأخذ قياسات حقلية من الطبيعة للتصرفات المارة على هدار حسن و اصف بالفيوم و معايرتها

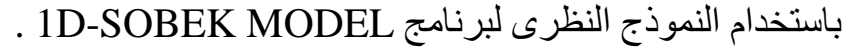

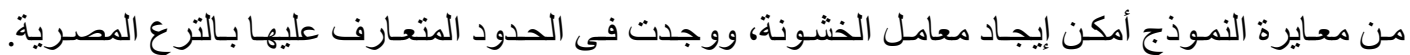

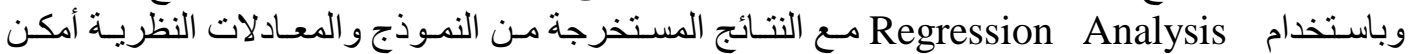

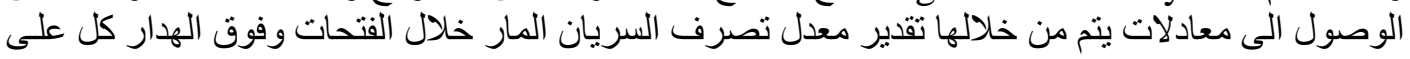

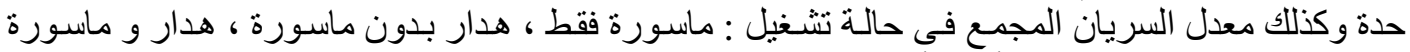

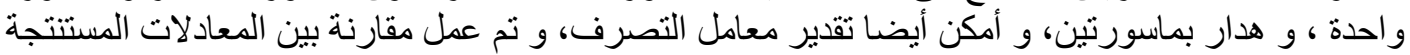

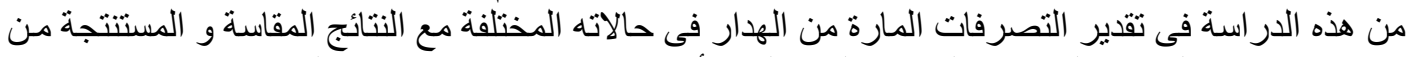

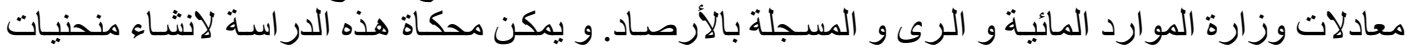

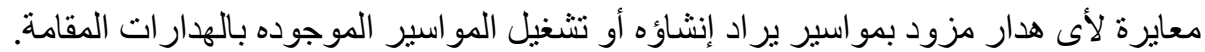

